\title{
L-イソロイシン型ゲル化剤を用いた超分子ゲルエマルション
}

\section{Supramolecular Gel Emulsion based on L-Isoleucine Organogelators}

\author{
鈴木 正浩 \\ 信州大学大学院総合工学系研究科 \\ 生命機能・ファイバー工学専攻 \\ 干 386-8567 \\ 長野県上田市常田 3-15-1 \\ Masahiro SUZUKI \\ Graduate School of Science and \\ Technology, Shinshu University \\ 3-15-1 Tokida, Ueda, Nagano \\ 386-8567, Japan
}
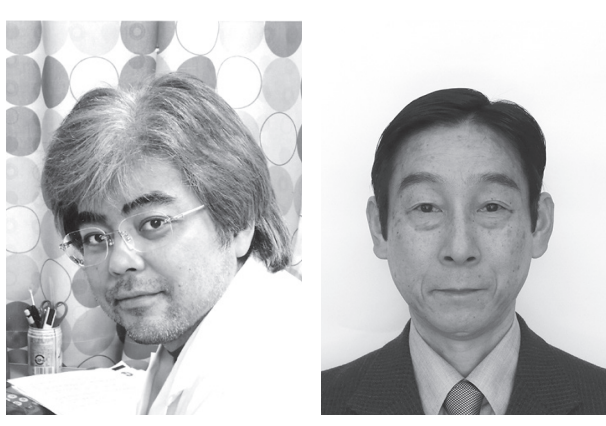

\author{
英 謙二 \\ 信州大学大学院総合工学系研究科 \\ 生命機能・ファイバー工学専攻 \\ 干 386-8567 \\ 長野県上田市常田 3-15-1 \\ Kenji HANABUSA \\ Graduate School of Science and \\ Technology, Shinshu University \\ 3-15-1 Tokida, Ueda, Nagano \\ 386-8567, Japan
}

論文要旨：L-アミノ酸系低分子ゲル化剤は，比較的簡単に合成でき優れたゲル化能を発揮する。中でも イソロイシン誘導体は，無極性溶媒，エステル油，ミネラル油，植物油あるいはシリコーン油をゲル化する。 本論文では，L-イソロイシン型低分子ゲル化剂を安定剂として使用した超分子ゲルエマルションの調製に ついて報告する。

Abstract: L-Amino acid-based low-molecular-weight gelators are prepared by simple synthetic procedures and function as an excellent organogelator. Especially, L-isoleucine-based LMW organogelators can form organogels in non-polar solvents, ester oils, mineral oils, vegetable oils and silicone oils. In this paper, we describe the preparation and property of supramolecular gel emulsion formed by Lisoleucine-based organogelators.

Key words: L-isoleucine, gelator, organogel, gel emulsion, nanofiber

\section{1 はじめに}

水と油のようにお互いに混じり合わない二つの液体に 乳化剤 (界面活性剤) を添加し, 擋挥等の機械的な操作 を加え，均一に分散した液／液系の乳濁液をエマルショ ンと呼ぶ ${ }^{1)}$ 。水中に細かい油滴が分散している水中油滴 （O/W）型あるいは油中に細かい水滴が分散している油 中水滴（W/O）型がある。食品の牛乳やマヨネーズ, 生クリーム, 化粧品の乳液やクリームなどが $\mathrm{O} / \mathrm{W}$ 型, 食品のバターやマーガリン，化粧品の日焼け止めなどが $\mathrm{W} / \mathrm{O}$ 型エマルションである。さらに W/O 型エマルショ ンが液滴として水に分散した $\mathrm{W} / \mathrm{O} / \mathrm{W}$ 型や $\mathrm{O} / \mathrm{W}$ 型エマ ルションが油に分散した $\mathrm{O} / \mathrm{W} / \mathrm{O}$ 型の複合エマルション も存在する。エマルションはどちらか片方だけでは生み 出すことのできない高機能性を発現し, 化粧品, 食品, 医薬品をはじめ, 農薬, 塗料, 接着剤, 紙加工, 印刷イ ンキ, 土木, エネルギーなど，幅広い産業分野で応用さ れている1)。

連絡者：鈴木 正浩

E-mail : msuzuki@shinshu-u.ac.jp
近年, ゲルエマルションとしても知られる高内相エマ ルション (HIPEs) は, 食品, 化粧品, 医薬品や塗料, コー ティングなどの様々な分野で幅広く応用できるため, 熱 心に研究されている ${ }^{2-5)}$ 。高内相エマルションは, 分散 相の体積を増加させていくと, 徐々に分散液滴間の距離 が接近し，球の最大充填の臨界值である $74 \%$ を超える と，著しく増粘性を増すことによってゲル状態となる ${ }^{6,7)}$ 。 このようなゲルエマルションは, 多孔質材料の作製 ${ }^{8-10)}$, 流出オイルの回収や電極材料 ${ }^{11)}$, 触媒反応 ${ }^{12)}$, 水素貯 蔵 ${ }^{13)}$ など様々な分野への応用が期待されている。しか しながら，ゲルエマルションを調製するための安定剤と して界面活性剤がよく用いられるが，その添加量が多い ためあまり効率的ではない。

一方で，低分子ゲル化剤を安定剤として用いると，低 濃度の添加量でゲルエマルションを形成することが報告 された ${ }^{14)}$ 。低分子ゲル化剤を安定剤として用いたゲル エマルションは, 高内相エマルションとは形成機構が異 なり，連続相をゲル化することによって液滴を物理的に トラップすることで形成されると考えられている。低分 子ゲル化剤は, 比較的少量の添加で, 油や有機溶媒, 水 
をゲル化する低分子化合物を指し，分子センサー，分子 デバイス，ドラッグデリバリーなどへの応用が期待され ている ${ }^{15-17)}$ 。筆者らも，L-アミノ酸を基盤とした低分

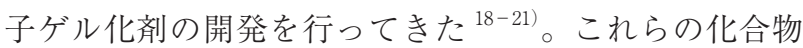
は多くの油や有機溶媒を比較的少量の添加でゲルを形成 できるゲル化剤である。また，生体構成成分であるアミ ノ酸を基盤としているため低環境負荷であり，幅広い分 野での応用が期待されている。本研究では, 超分子ゲル エマルションを作製するための L-イソロイシンを基盤 とした低分子ゲル化剤の合成とその超分子ゲルエマル ション化能について調査した結果を報告する。

\section{2 ゲル化剂の分子設計と特性評価}

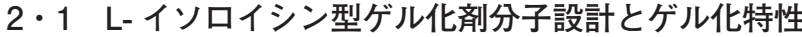

まず，今まで当研究室で合成されてきたL-イソロイ シン型低分子ゲル化剂を用いて，水と油からなる超分子 ゲルエマルションの作製を試みた。しかしながら，これ らのゲル化剂は，油類に対して優れたゲル化能を持つに もかかわらず，超分子ゲルエマルションを形成できな かった。具体的に, 油層のみゲル化したり, ゲルエマル ションが形成されても数分から数時間で崩壊したりし た。通常，安定したゲルエマルションを作製するために は，安定剤として界面活性剤を投入するため，これらの ゲル化剤には界面活性剤としての機能を持っていないた めと推測できる。そこで，ゲル化剤に界面活性剂様のセ グメントを導入することが得策と考え, L-イソロイシ ン誘導体の末端に界面活性剂部位，ここではポリエチレ

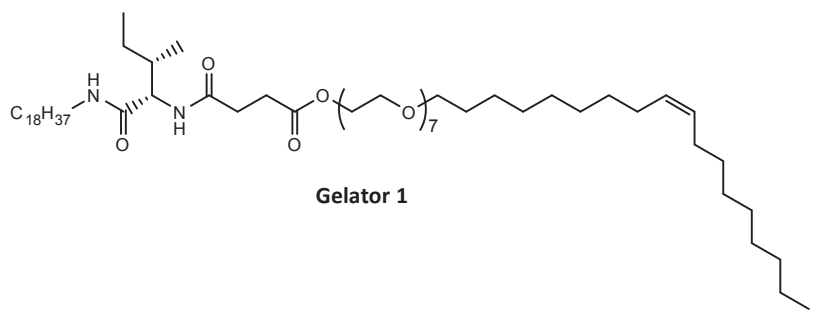

Fig. 1 界面活性剤を導入したL-イソロイシン型ゲル化剂
ングリコールモノオレイルエーテル（エチレングリコー ル部位の平均重合度が約 7 のの), を導入した Gelator 1 （Fig. 1）を合成した。

次に, Gelator 1 の種々の有機溶媒や油類に対するゲ ル化テストを行い, その結果をTable 1 に示した。ここで, カッコ内の数字は, 最小ゲル化濃度 $(\mathrm{MGC}, \mathrm{mg} / \mathrm{mL})$ を示す。Gelator 1 は, 炭化水素系溶媒やエステル油, 油類, シリコーンオイルなどに対し, 低濃度で超分子ゲ ルを形成した。また純水には不溶であった。したがって， Gelator 1 は, 油水に対して優れたゲル化能を有し, ゲ ルエマルションを形成するための安定剤として使用でき る可能性があることが示唆された。

\section{$2 \cdot 2$ 超分子ゲルエマルションの作製}

超分子ゲルエマルションの作製は Scheme 1 に示した 方法で行った。 $1 \mathrm{~mL}$ の油へ Gelator 1 を加熱溶解し, 純水を添加した後, ミキサーで 1 分間混合した。サンプ ル瓶を室温で静置すると数分以内に超分子ゲルエマル ションが形成した。

Table 2 は, 油剤としてへキサン, ドデカン, 流動パ ラフィン, スクワラン, IPM, シリコーン油を用い, 種々 の水相比で超分子ゲルエマルション化試験を行った結果 をまとめたものである。ここで表中の $\triangle$ は超分子ゲルエ
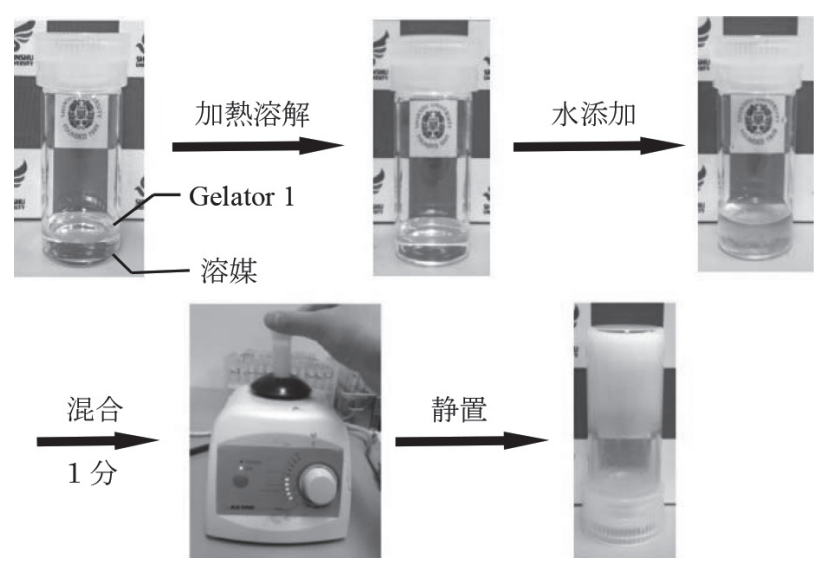

Scheme 1 超分子ゲルエマルションの作製手順

Table 1 Gelator 1 のゲル化テストの結果

\begin{tabular}{|c|c|c|c|}
\hline 溶媒 & 状態（MGC） & 溶媒 & 状態 (MGC) \\
\hline ドデカン & 透明ゲル（8） & 亜麻仁油 & 透明ゲル（8） \\
\hline 流動パラフィン & 透明ゲル (2) & ひまし油 & 半透明ゲル (40) \\
\hline スクワラン & 透明ゲル (2) & シリコーン油（KF56） & 透明ゲル (4) \\
\hline ミリスチン酸イソプロピル (IPM) & 半透明ゲル（10） & 灯油 & 透明ゲル (4) \\
\hline オレイン酸 & 溶液 & 軽油 & 透明ゲル（8） \\
\hline 大豆油 & 透明ゲル（4） & 水 & 不溶 \\
\hline
\end{tabular}

カッコ内の数值は最小ゲル化濃度（MGC, $\mathrm{mg} / \mathrm{mL}$ ) を示し, $1 \mathrm{~mL}$ の溶媒をゲル化できるゲル化剤の最小量 をmg 単位で表している。 
Table 2 超分子ゲルエマルション化テストの結果

\begin{tabular}{|c|c|c|c|c|c|c|}
\hline \multirow{2}{*}{$\begin{array}{c}\text { 水相比 } \\
(\mathrm{Vol} \%)\end{array}$} & ヘキサン & ドデカン & 流動パラフィン & スクワラン & IPM & $\begin{array}{c}\text { シリコーン油 } \\
(\mathrm{KF} 56)\end{array}$ \\
\hline 10 & $\mathrm{GE}(20)$ & $\mathrm{GE}(20)$ & $\mathrm{GE}(8)$ & $\mathrm{GE}(8)$ & $\mathrm{GE}(10)$ & $\mathrm{GE}(8)$ \\
\hline 20 & $\mathrm{GE}(20)$ & $\mathrm{GE}(20)$ & $\mathrm{GE}(8)$ & $\mathrm{GE}(8)$ & $\mathrm{GE}(10)$ & $\mathrm{GE}(8)$ \\
\hline 30 & $\mathrm{GE}(20)$ & $\mathrm{GE}(20)$ & $\mathrm{GE}(8)$ & $\mathrm{GE}(8)$ & $\mathrm{GE}(10)$ & $\mathrm{GE}(8)$ \\
\hline 40 & $\mathrm{GE}(20)$ & $\mathrm{GE}(20)$ & $\mathrm{GE}(8)$ & $\mathrm{GE}(8)$ & $\mathrm{GE}(10)$ & $\mathrm{GE}(8)$ \\
\hline 50 & $\mathrm{GE}(20)$ & $\mathrm{GE}(20)$ & $\triangle$ & $\mathrm{GE}(8)$ & $\mathrm{GE}(10)$ & $\mathrm{GE}(8)$ \\
\hline 60 & $\mathrm{GE}(20)$ & $\mathrm{GE}(20)$ & $\times$ & $\triangle$ & $\mathrm{GE}(10)$ & $\mathrm{GE}(10)$ \\
\hline 70 & $\mathrm{GE}(20)$ & $\mathrm{GE}(20)$ & $\times$ & $\times$ & $\mathrm{GE}(40)$ & $\triangle$ \\
\hline 80 & $\triangle$ & $\triangle$ & $\times$ & $\times$ & $\triangle$ & $\times$ \\
\hline
\end{tabular}

GE は超分子ゲルエマルションの形成, カッコの数字は超分子ゲルエマルション形成に必要なゲル化剂の最小濃度（mg/ $\mathrm{mL}$ ）を表す。 $\triangle$ : 超分子ゲルエマルション形成後数時間以内に崩壊したもの；×超分子ゲルエマルションを形成しな いもの。

マルション生成後, 数時間で 2 層に分離した状態，×は 超分子ゲルエマルションを作成しなかったことをそれぞ れ示す。油相にn-ドデカン, n-ヘキサンおよびIPMを 用いた場合，10-70 vol\%という幅広い水相比で超分子ゲ ルエマルションを形成した。また, 油相にシリコーン油, スクワラン，流動パラフィンを用いた場合は，それぞれ 水相比 10-60 vol\%，10-50 vol\%，10-40 vol\%で超分子ゲ ルエマルションを形成することがわかった。そして，超 分子ゲルエマルションの形成は, 油剤の種類に著しく依 存した。

一般的に，ゲルエマルションとしても知られる高内相 エマルション (HIPEs) は, 分散相の体積が $74 \%$ を超 えると, 著しく増粘性を増すことによって形成される ${ }^{6}$ 。 また，ゲルエマルションを調製するための安定剤として 界面活性剤が用いられるが，連続相に対して 5-50\%（w/ v）添加しなければならず，あまり効率的ではない。 Gelator 1 は，10-70 vol\%という幅広い水相比でゲルエ マルションを形成可能であり, 特に低水相比でもゲルエ マルションの作製が可能であることがわかった。加えて, ゲル化剤濃度 $40 \mathrm{mg} / \mathrm{mL}$ 以下という低い安定剂の濃度 でゲルエマルションの作製が可能であることがわかっ た。

\section{3 超分子ゲルエマルションの特性評価}

\section{$3 \cdot 1$ 超分子ゲルエマルションの型}

超分子ゲルエマルションの型を判別するため, 光学顕 微鏡観察を行った。Gelator 1 の濃度は $40 \mathrm{mg} / \mathrm{mL}$, 油 相にn-ドデカン，水相にメチレンブルー水溶液を用い て調製した。

Fig. 2a は, 超分子ゲルエマルションの光学顕微鏡写 真を示す。直径が 10-100 マイクロメートルの液滴が観
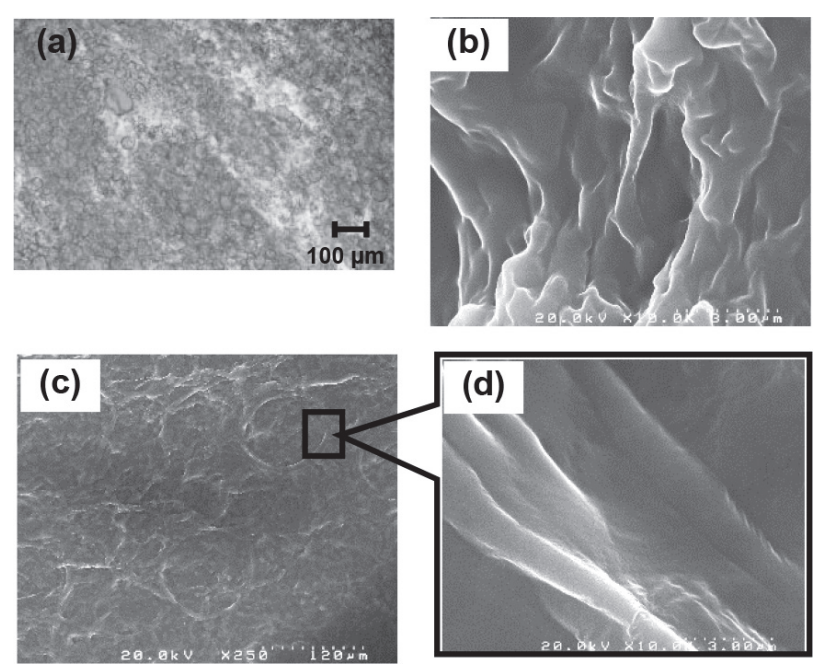

Fig. 2 （a）超分子ゲルエマルションの光学顕微鏡写真，（b） ドデカンゲルから調製した乾燥ゲルの FE-SEM 画像, （c）（d）超分子ゲルエマルションから調製した乾燥 ゲルの FE-SEM 画像

測された。また，液滴が青く染色されていたことから， 水相が分散相, 油相が連続相である W/O 型のエマル ションであると考えられる。

\section{$3 \cdot 2$ 電子顕微鏡観察}

Gelator 1 は, 油／水系に対して連続相（油相）中に 水相が液滴として分散し, 超分子ゲルエマルションを形 成することがわかった。そこで，超分子ゲルエマルショ ン中での Gelator 1 のナノ構造を FE-SEM を用いて観察 した。Fig. 2 に Gelator 1 からなるドデカンゲルおよび ドデカン／水（1：1 vol\%）の超分子ゲルエマルション から調製したサンプルの FE-SEM 画像を示した。Fig. 2b から, Gelator 1 がドデカンゲル中で直径数 100 ナノ メートルのナノファイバーとそれらが絡まりあった 3 次 元網目構造を形成していることがわかった。これは, 一 
般的な低分子ゲル化剂が低分子ゲル中で形成するナノ構 造に類似している。

一方, 超分子ゲルエマルション中の構造を見てみると, 低倍率では, 網目構造中に 100 マイクロメートル程度の 空孔がいくつか観測された（Fig. 2c）。これは光学顕微 鏡によって観察された液滴の直径と類似しているため, これらの空孔は分散相（水相）由来であり，それ以外の 部分は連続相（ドデカン相）であると考えられる。高倍 率で観察すると，ドデカンゲル中と同様に直径数 100 ナ ノメートルのナノファイバーが観測された（Fig. 2d）。 したがって，超分子ゲルエマルションは，分散相が連続 相中のナノファイバーに取り囲まれている構造であるこ とが示唆された。つまり, Gelator 1 によるゲルネット ワークが連続相を固化し，マイクロメーターサイズの水 滴を物理的にトラップすることで安定な超分子ゲルエマ ルションを形成していると考えられる。おそらく, Gelator 1 中のエチレングリコール部分が水滴と相互作 用して，水滴の合一を防ぐと思われる。

\section{$3 \cdot 3$ FT-IR スペクトル測定}

Gelator 1 からなるドデカンゲルおよびドデカン／水 超分子ゲルエマルションの FT-IR 測定を行った。ドデ カンゲル中では, 水素結合したアミド基に由来する $1636 \mathrm{~cm}^{-1}$ にアミド I バンドが観察された。この結果は, Gelator 1 がアミド基間の水素結合を主な駆動力として ナノファイバーへ自己集合していることを示している。 一方，超分子ゲルエマルションの FT-IR スペクトルは, $1634 \mathrm{~cm}^{-1}$ にアミドIのピークを示した。これは，ゲル エマルション中においても，アミド基間の水素結合を主 な駆動力としナノファイバーを形成していることを示唆 する。さらに, Gelator 1 は超分子ゲルエマルション中
でも連続相であるドデカン中でゲルを形成しているた め，類似の IR スペクトルが観測されたと考えられる。

\section{3 -4 超分子ゲルエマルションの熱安定性と強度}

超分子ゲルエマルションの物性は，超分子ゲルエマル ションの崩壊温度およびゲル強度を測定することで評価 した。Fig. 3 に，種々の水相比で作製した超分子ゲルエ マルションの崩壊温度（Fig. 3a）およびゲル強度（Fig. 3b）をプロットした。ここで, Fig. 3aにプロットした 点は，ゲルおよびゲルエマルションから溶媒が染み出し たり，軽く吒いてゲルエマルションが崩れた温度であ る。また，水相比 $0 \%$ はドデカンゲルのデータである。 Gelator 1 の濃度が $40 \mathrm{mg} / \mathrm{ml}$ のとき，ドデカンゲルは $50^{\circ} \mathrm{C}$ で崩壊した。一方, 超分子ゲルエマルションは, 崩 壊温度が $55^{\circ} \mathrm{C}$ （水相比が $70 \mathrm{vol} \%$ ） $65^{\circ} \mathrm{C}$ （水相比が 10-60 vol\%）となり，ドデカンゲルと比べると高い熱安 定性を持ち，水相比が増加すると熱安定性が低下するこ とがわかった。また, Gelator 1 の濃度が $20 \mathrm{mg} / \mathrm{mL} の$ ときも, $40 \mathrm{mg} / \mathrm{mL}$ のときりは熱安定性は低下するが, ほほ同様な傾向を示した。これは，アミド基間の水素結 合に加えて, 水滴とナノファイバー間の相互作用が起 こっている可能性を示唆する。

次に，ゲル強度を比較した。Fig. 3bは，超分子ゲル エマルションのゲル強度と水相比の関係を示す。ここで, 直径 $1 \mathrm{~cm}$ のテフロンバーをゲルへ $4 \mathrm{~mm}$ 浸漬させたと きの応力から得られる值をゲル強度と定義した。眓から ゲル強度は, Gelator 1 の濃度や超分子ゲルエマルショ ン中の水相比が増加すると小さくなった。例えば, Gelator 1 の濃度が $40 \mathrm{mg} / \mathrm{mL}$ の場合, ドデカンゲルで は $517 \mathrm{~g} / \mathrm{cm}^{2}$ ，水相比 $10 \mathrm{vol} \%$ では $310 \mathrm{~g} / \mathrm{cm}^{2}, \quad 50 \mathrm{vol} \%$ では $177 \mathrm{~g} / \mathrm{cm}^{2}$ ，水相比 $70 \mathrm{vol} \%$ では $130 \mathrm{~g} / \mathrm{cm}^{2}$ 。超分
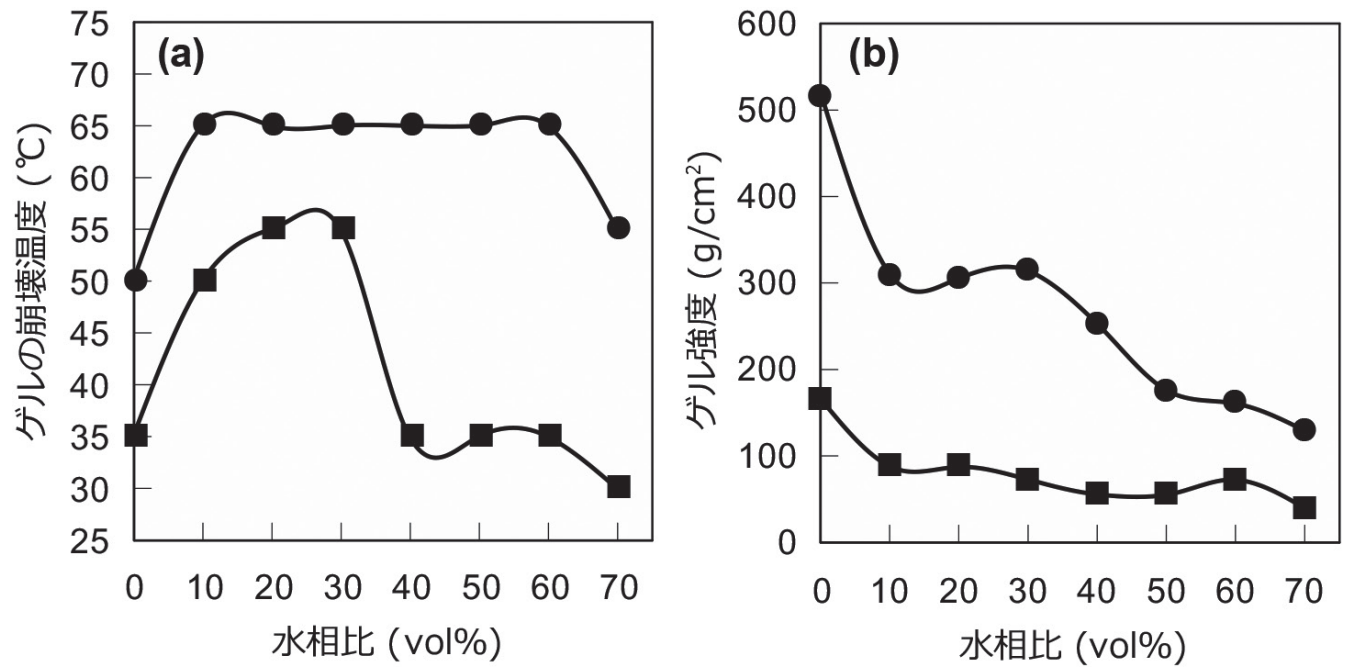

Fig. 3 （a）超分子ゲルエマルションの崩壊温度と水相比の関係（b）超分子ゲルエマルションのゲル強度と水相比の関係 ドデカン $/$ 水 $=50: 50$ (vol\%)；ゲル化剂濃度 $=20 \mathrm{mg} / \mathrm{mL}$

(ロ), $40 \mathrm{mg} / \mathrm{mL}$ 


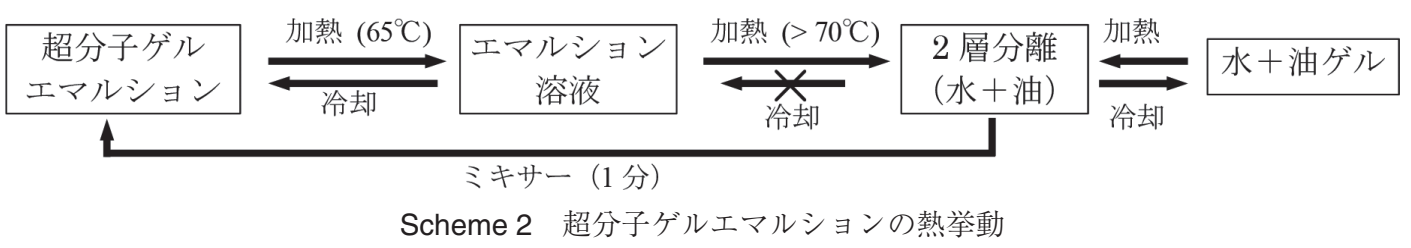

子ゲルエマルション中では，ドデカンゲルの中にマイク ロメーターサイズの水滴が分散している構造をとってい るため, 超分子ゲルエマルションのゲル強度が低くな る。また, ゲルエマルション中の水滴の数（水相比に相 当）の増加に伴って，ゲル強度も低下する。

さらに, 超分子ゲルエマルションは Scheme 2 に示す ような特異的な熱挙動を示した。Gelator 1 の濃度が 40 $\mathrm{mg} / \mathrm{mL}$ の $50 \mathrm{vol} \%$ の超分子ゲルエマルションは, $65^{\circ} \mathrm{C}$ で流動的なエマルションとなり，冷却すると元に戻る。 この過程は可逆的である。一方, $65^{\circ} \mathrm{C}$ へ加熱して形成さ れたエマルション溶液を $70^{\circ} \mathrm{C}$ 以上で再加熱すると, エ マルションは崩壊して水と油の 2 層溶液へ変化する。こ の 2 層溶液を泠却すると油ゲルと水が分離した構造とな り，超分子ゲルエマルションを形成することはなかっ た。しかしながら，2 層分離した溶液をミキサーで混合 しながら冷却すると, 再び超分子ゲルエマルションが形 成した。このことは, 超分子ゲルエマルションが $65^{\circ} \mathrm{C}$ までは可逆的なゲルエマルションーエマルション相転移 を起こすことを示している。

\section{4 おわりに}

本研究では, 超分子ゲルエマルションを作製するため に，界面活性剤セグメントを導入したL-イソロイシン 型低分子ゲル化剂（Gelator 1）を合成した。Gelator 1 は無極性溶媒，エステル油，植物油，鉱物油およびシリ コーン油を効率よくゲル化した。そして, Gelator 1 を 含む油と水から安定な W/O 型超分子ゲルエマルション の作製に成功した。これらの超分子ゲルエマルションは, 低水相比でも安定である。電子顕微鏡観察やその他の機 器分析結果から, Gelator 1 が油をゲル化しその中に $100 \mu \mathrm{m}$ 程度の水滴を保持していることがわかった。こ れは, Gelator 1 が形成するゲルネットワークによって 油を固化し，ナノファイバーが水滴を取り囲むように存 在することで, 合一を妨げ, 安定したゲルエマルション を形成していると考えられる。これらの結果は, 低分子 ゲル化剤へ界面活性剤部位を導入することで, 幅広い水 相比で超分子ゲルエマルションを作製できることを示し ている。また, 従来のゲルエマルションと比べ調製方法
が簡単で安定雯濃度（ゲル化剂濃度）が低いことも，工 業化における大きな利点であると考えられる。

\section{文 献}

1）堀内照夫, 乳化技術と乳化剂の開発, シーエムシー出 版 (2004).

2) H. Bartl, W. Bonnin, Makromol. Chem., 57, 74-95 (1962).

3) K. J. Lissant, K. G. J. Mayhan, J. Colloid Interface Sci., 42, 201-208 (1973).

4) R. Butler, C. M. Davies et al. Adv. Mater, 13, 1459-1463 (2001).

5) N. R. Cameron, D. P. Gregory et al. Colloid Polym. Sci, 274, 592-595 (1996).

6) K. J. Lissant, J. Colloid Interface Sci., 22, 462-468 (1996).

7) F. Su, C. L. Bray et al., Adv. Mater, 20, 2663-2666 (2008).

8) H. F. Zhang, A. I. Cooper, Soft Matter, 1, 107-113(2005).

9) S. D. Kimmins, N. R. Cameron, Adv. Funct. Matter, 21, 211-225 (2011).

10) N. Brun, S. Ungureanu, H. Deleuze, R. Backov, Chem. Soc. Rev, 40, 771-788 (2011).

11) H. F. Zhang, A. I. Cooper et al., Adv. Mater, 16, 27-30 (2004).

12) A. Desforges, R. Backov et al., Langmuir, 4, 656-662 (1988).

13）角田光雄, 機能性エマルションの技術と評価, シーエ ムシー出版 (2007).

14) X. Chen, Y. Fang et al., Langmuir, 28, 9275-9281 (2012).

15) P. Terech \& R. G. Weiss, Chem. Rev., 97, 3133-3160 (1997).

16) L. A. Estroff \& A. D. Hamilton, Chem. Rev., 104, 12011218 (2004).

17) P. Terech \& R. G. Weiss, Molecular Gels: Materials with Self-Assembled Fibrillar Networks. Springer, Dordrecht (2006).

18) M. Suzuki \& K. Hanabusa, Chem. Soc. Rev., 38, 967975 (2009).

19) M. Suzuki \& K. Hanabusa, Chem. Soc. Rev., 39, 455463 (2010).

20) K. Hanabusa \& M. Suzuki, Bull. Chem. Soc. Jpn., 89, 174-182 (2016).

21）鈴木正浩（監), 低分子ゲルの開発と応用, シーエムシー 出版 (2016). 